\title{
PENGARUH MODEL PROJECT BASED LEARNING TERHADAP HASIL BELAJAR SISWA PADA MATERI POKOK FLUIDA STATIS
}

\author{
Pintor Simamora dan Masitoh \\ pintorsimamora@gmail.com \\ Jurusan Fisika Fakultas MIPA Universitas Negeri Medan \\ Jalan Willem Iskandar Pasar V Medan, 20221
}

\begin{abstract}
This study aims to determine the student learning outcomes and learning activities of students who are taught with a project-based learning models in the subject matter in a static fluid at Class XI Semester II in Madrasah Aliyah Negeri I Medan TP 2013/2014. This research is quasiexperimental. The study population was all students inclass XI Science Semester II Aliyah Negeri I Field which consists of 6 classes. Sampling was done by cluster random sampling, a class XI IPA1selected as the experimental class and the class as a class XI IPA 2 control. The instrument used is the achievement test in the form of multiple-choice and observation sheets that have done test requirements. Experimental class treatment given to the model project based learning and class room control with conventional learning models. Data on average 45.7 pretest experimental class and control class average of 43.8. pretest data testing showed that the ability of both classes of students at the beginning of the second class of the same. After completion of the study, the data obtained posttest with an average grade of 70.2 experimental and control class average of 65.4. Normality and homogeneity test showed that the two classes are normally distributed and homogeneous, then test the hypothesis that the data obtained post test tcount $>t$ table(4.002>2.015) then His accepted that there is a significant difference due to the influence model of project-based learning on learning outcomes of students in the subject matter fluid static at class XI Semester II in Madrasah Aliyah Negeri I Medan TP 2013/2014. During the learning process, the average data of student learning activities in classes taught project-based learning modelis $77.5 \%$ with the active category.
\end{abstract}

Keywords: project-based learning model, student learning outcomes

\section{PENDAHULUAN}

Pendidikan interaksi yang mendorong terjadinya belajar. Sekolah merupakan salah satu lembaga formal yang menyelenggarakan dan melaksanakan serangkaian kegiatan belajar yang meliputi berbagai mata pelajaran, sehingga diperlukan perencanaan pembelajaran yang baik sehingga mencapai salah satu dari tujuan Pendidikan Nasional. 


\begin{abstract}
Para peneliti bidang pendidikan fisika di Indonesia menyebutkan beragam alasan mengenai kurangnya pemahaman siswa tentang fisika. Dalam proses belajar mengajar kemampuan dan cara mengajar guru ditengarai sebagai penyebab lemahnya pemahaman fisika pada siswa.

Oleh karena itu dibutuhkan suatu perubahan dengan cara mengajar guru, yang salah satunya dengan menggunakan model pembelajaran yang dapat meningkatkan aktivitas siswa selama proses pembelajaran. Model pembelajaran tersebut harus dapat membuat peserta didik mencari informasi sendiri dan saling
\end{abstract} bertukar fikiran.

$\begin{array}{ccc}\text { Salah } & \text { satu } & \text { model } \\ \text { pembelajaran } & \text { yang } & \text { dapat }\end{array}$
mengaktifkan siswa selama proses pembelajaran yaitu Pembelajaran Berbasis Proyek. Buck Institute for Education (Sutirman, 2013) menyatakan bahwa "pembelajaran berbasis proyek adalah suatu metode pengajaran sistematis yang melibatkan para siswa dalam mempelajari pengetahuan dan keterampilan melalui proses yang terstruktur, pengalaman nyata dan teliti yang dirancang untuk menghasilkan produk". Pembelajaran berbasis proyek merupakan model pembelajaran yang sesuai dalam penyempurnaan kurikulum KTSP menjadi kurikulum 2013. Menurut Permendikbud No. 65 tahun 2013 tentang standar proses, perlu diterapkan pembelajaran dengan metode berbasis penyingkapan/penelitian (Discovery/Inquiry) dan pembelajaran yang menghasilkan karya berbasis pemecahan masalah (project based learning) yang dapat mendorong kemampuan peserta didik untuk menghasilkan karya yang kontekstual.Model pembelajaran berbasis proyek menjadikan peserta didik sebagai pusat pembelajaran (student centered active learnig) yang memberikan kesempatan sebesarbesarnya pada siswa untuk mengeksplor kemampuan siswa, sedangkan guru bertindak sebagai fasilitator. Pembelajaran berbasis proyek membuat siswa membentuk sendiri konsep ilmu pengetahuan yang peserta didik pelajari. Berdasarkan bahasan tersebut penulis tertarik untuk melakukan penelitian tentang Model Pembelajaran Berbasis Proyek (Project Based Learning) sebagai bahan penyusunan skripsi dengan judul : Pengaruh Model Project Based Learning Terhadap Hasil Belajar Siswa Pada Materi Pokok Fluida Statis di Kelas XI Semester II MAN 1 Medan

\section{METODE PENELITIAN}

Penelitian ini dilaksanakan di MAN 1 Medan yang beralamat di Jl. Williem Iskandar 7B Medan, pada bulan Maret 2014 semester II di kelas XIT.P. 2013/2014.

Populasi penelitian adalah seluruh siswa kelas XIMAN 1 Medan yang terdiri dari 6 kelas. Dari seluruh kelas XI IPA, yang menjadi sampel penelitian ini adalah dua kelas yaitu kelas XI IPA ${ }_{1}$ berjumlah 22 orang sebagai kelas eksperimen yang diajar dengan model project based learning

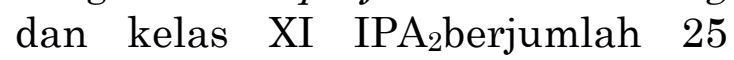
orang sebagai kelas kontrol yang diajar dengan model pembelajaran 
konvensional. Pengambilan sampel ini dilakukan secara cluster random sampling dimana populasi terdiri dari kelompok-kelompok atau cluster, dan penelitian dilakukan pada kelas sebagai kelompok.

Penelitian ini termasuk jenis penelitian quasi eksperimen yaitu merupakan penelitian yang dimaksudkan untuk mengetahui ada tidaknya akibat dari sesuatu yang dikenakan pada subjek yaitu siswa.

Penelitian ini melibatkan dua kelas yang diberi perlakuan yang berbeda. Untuk mengetahui hasil belajar fisika siswa dilakukan dengan memberikan tes pada kedua kelas sebelum dan sesudah diberikan perlakuan. Rancangan penelitian ini dapat dilihat pada tabel sebagai berikut:

Tabel 1. Two Group Pretes Posttest Design

\begin{tabular}{|c|c|c|c|}
\hline Kelas & Pretes & Perlakuan & Postes \\
\hline Eksperimen & $\mathrm{T}_{1}$ & $\mathrm{X}_{1}$ & $\mathrm{~T}_{2}$ \\
\hline Kontrol & $\mathrm{T}_{1}$ & $\mathrm{X}_{2}$ & $\mathrm{~T}_{2}$ \\
\hline
\end{tabular}

Keterangan :

$\mathrm{X}_{1}=$ Pembelajaran dengan menggunakan model project based learning

$\mathrm{X}_{2}=$ Pembelajaran dengan menggunakan model pembelajaran konvensional.

$\mathrm{T}_{1}=$ Pretes diberikan kepada kelas eksperimen dan kelas kontrol sebelum perlakuan.

$\mathrm{T}_{2}=$ Postes diberikan setelah perlakuanpada kelas eksperimen dan kelas control.

Dari hasil pretest yang dipeoleh dilakukan uji Normalitas, uji Homogenitas dan uji kesamaan rata-rata (uji-t) untuk menentukan apakah data berdistribusi normal, homogen dan tidak ada perbedaan yang signifikan antara hasil belajar kedua kelas. Selanjutnya kedua kelas diberi perlakuan yang berbeda, kelas eksperimen diberi perlakuan dengan menggunakan model project based learning dan kelas kontrol diberi perlakuan dengan menggunakan model pembelajaran konvensional. Setelah itu kedua kelas diberi postes. Dari hasil postes yang diperoleh dilakukan kembali uji Normalitas, Homogenotas dan uji kesamaan rata-rata (uji-t) untuk menentukan apakah data hasil belajar siswa digolongkan normal, homogen dan ada perbedaan yang signifikan antara hasil belajar kedua kelas yang menginduksi bahwa ada pengaruh atau tidak model project based learning terhadap hasil belajar siswa.

\section{HASIL DAN PEMBAHASAN}

Data dari hasil penelitian ini berupa hasil belajar siswa yaitu pretest dan posttest dan hasil observasi pada tabel 2 :

Tabel 2. Data Pretes Kelas

Eksperimen dan Kelas Kontrol

\begin{tabular}{|c|c|c|c|c|c|}
\hline \multicolumn{3}{|c|}{ Kelas Eksperimen } & \multicolumn{3}{|c|}{ Kelas Kontrol } \\
\hline Nilai & $\begin{array}{c}\text { Frek } \\
\text { uens } \\
\text { i }\end{array}$ & $\begin{array}{c}\text { Rat } \\
\mathrm{a}^{-} \\
\text {rata }\end{array}$ & $\begin{array}{c}\text { Nila } \\
\text { i }\end{array}$ & $\begin{array}{l}\text { Frek } \\
\text { uensi }\end{array}$ & $\begin{array}{l}\text { Rata- } \\
\text { rata }\end{array}$ \\
\hline 20 & 1 & \multirow{10}{*}{45,7} & 25 & 2 & \multirow{10}{*}{43,8} \\
\hline 30 & 1 & & 30 & 3 & \\
\hline 35 & 3 & & 35 & 2 & \\
\hline 40 & 4 & & 40 & 5 & \\
\hline 45 & 2 & & 45 & 3 & \\
\hline 50 & 5 & & 50 & 4 & \\
\hline 55 & 3 & & 55 & 3 & \\
\hline 60 & 2 & & 60 & 2 & \\
\hline 65 & 1 & & 65 & 1 & \\
\hline \multicolumn{2}{|c|}{$\Sigma=22$} & & \multicolumn{2}{|c|}{$\Sigma=25$} & \\
\hline
\end{tabular}


Selain data pretes pada penelitian ini juga diperoleh data postes dengan rincian pada tabel 3 sebagai berikut:

Tabel 3. Data Postes Kelas Eksperimen dan Kelas Kontrol

\begin{tabular}{|c|c|c|c|c|c|}
\hline \multicolumn{3}{|c|}{$\begin{array}{c}\text { Kelas } \\
\text { Eksperimen }\end{array}$} & \multicolumn{3}{|c|}{ Kelas Kontrol } \\
\hline $\begin{array}{c}\mathrm{Nil} \\
\text { ai }\end{array}$ & $\begin{array}{l}\text { Frek } \\
\text { uensi }\end{array}$ & $\begin{array}{c}\text { Rat } \\
\mathrm{a}^{-} \\
\text {rata }\end{array}$ & $\begin{array}{l}\text { Nila } \\
\text { i }\end{array}$ & $\begin{array}{l}\text { Frek } \\
\text { uensi }\end{array}$ & $\begin{array}{c}\text { Rat } \\
\mathrm{a}^{-} \\
\text {rata }\end{array}$ \\
\hline 50 & 3 & \multirow{10}{*}{70,2} & 50 & 1 & \multirow{10}{*}{65,4} \\
\hline 55 & 3 & & 55 & 4 & \\
\hline 60 & 3 & & 60 & 6 & \\
\hline 65 & 1 & & 65 & 5 & \\
\hline 70 & 1 & & 70 & 3 & \\
\hline 75 & 5 & & 75 & 3 & \\
\hline 80 & 1 & & 80 & 1 & \\
\hline 90 & 4 & & 85 & 1 & \\
\hline 100 & 1 & & 90 & 1 & \\
\hline \multicolumn{2}{|c|}{$\Sigma=22$} & & \multicolumn{2}{|c|}{$\Sigma=25$} & \\
\hline
\end{tabular}

Penelitian diawali dengan memberikan pretes terhadap kedua sampel dengan jumlah soal 20 butir dalam bentuk pilihan berganda dengan 5 opsi yaitu pada kelas eksperimen dan kelas kontrol. Hasil pretes kelas eksperimen memperoleh nilai rata-rata 45,7 dan nilai rata-rata kelas kontrol adalah 43,8. Dengan menggunakan uji t dua pihak ternyata hasil tersebut menyatakan bahwa tidak ada perbedaan yang signifikan antara kemampuan awal siswa pada kelas eksperimen terhadap kemampuan awal siswa pada kelas kontrol sebelum diberi perlakuan.

Kemudian pada kedua kelas diberi perlakuan yang berbeda yaitu pada kelas eksperimen diberi perlakuan menggunakan model project based learning sedangkan kelas kontrol diberi perlakuan dengan menggunakan model pembelajaran konvensional. Setelah diberikan perlakuan kedua kelas diberikan tes akhir (postes) untuk melihat adanya pengaruh yang signifikan terhadap hasil belajar siswa. Hal ini dapat dilihat dari hasil rata-rata postes kelas eksperimen yaitu 70,2, sedangkan nilai rata-rata postes kelas kontrol 65,4. Hasil uji normalitas untuk kedua sampel menunjukkan bahwa kedua kelas berdistribusi normal dimana Lhitung tidak melebihi Llabel dan berasal dari populasi yang homogen. Hasil uji hipotesis untuk postes menggunakan uji $t$ satu pihak pada taraf signifikan $\alpha=0,05$ diperoleh $t_{\text {hitung }}>t_{\text {tabel }}(4,002>2,015)$ yang berarti bahwa ada pengaruh yang signifikan akibat pengaruh model project based learning terhadap hasil belajar siswa.

Observasi dilakukan pada kegiatan diskusi untuk tiap pertemuan yang terdiri dari empat kali pertemuan. Observasi dilakukan hanya pada kelas eksperimen. Hasil perkembangan aktivitas belajar siswa dapat dilihat pada grafik berikut:

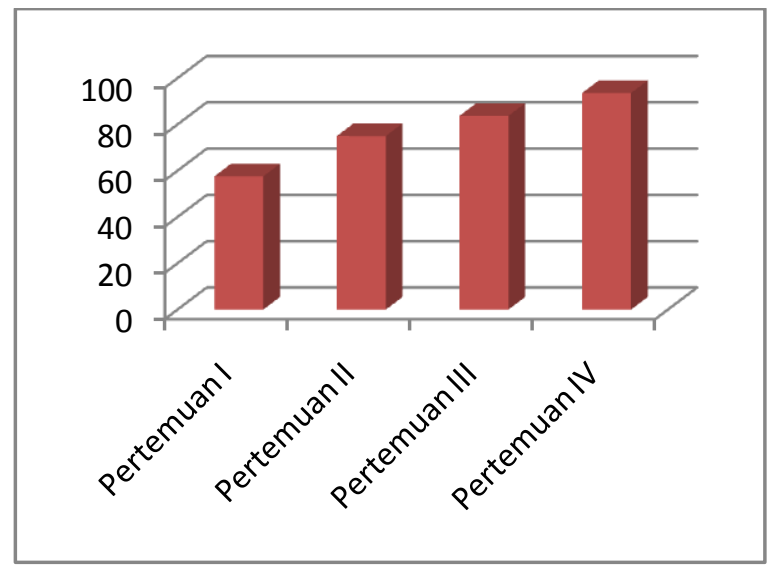

Gambar 1. Grafik Aktifitas belajar siswa pada kelas eksperimen 
Dari gambar diatas dapat dilihat bahwa perkembangan aktivitas siswa di kelas eksperimen mengalami peningkatan selama menerima pembelajaran dengan menggunakan model project based learning.

\section{KESIMPULAN}

Berdasarkan data hasil penelitian yang diperoleh dan analisa data serta pengujian hipotesis maka dapat disimpulkan sebagai berikut:

1. Aktivitas belajar siswa selama mengikuti pembelajaran dengan menggunakan model project based learning pada materi pokok fluida statis di kelas XI semester II MAN 1 Medan T.P. 2013/2014 adalah meningkat dan diperoleh rata-rata skor aktivitas belajar siswa pada keempat pertemuan mencapai $77,5 \%$ dengan kategori aktif.

2. Nilai rata-rata hasil belajar siswa pada kelas eksperimen setelah diberi perlakuan dengan model project based learning adalah 70,2 tergolong tidak tuntas secara kelas, secara individu terdapat 11 siswa yang tuntas dan 11 siswa tidak tuntas.

3. Nilai rata-rata hasil belajar siswa pada kelas kontrol yang diberi perlakuan dengan model pembelajaran konvensional adalah 63,82 tergolong tidak tuntas secara kelas, secara individu terdapat 6siswa yang tuntas dan 19 siswa tidak tuntas.

4. Ada perbedaan yang signifikan akibat pengaruh model project based learning terhadap hasil belajar siswa pada materi pokok fluida statis di kelas XI Semester II MAN 1 Medan T.P. 2013/2014.

\section{DAFTAR PUSTAKA}

Fathurrohman, P., dan Sutikno, M., (2007), Strategi Belajar Mengajar, PT Refika Aditama, Bandung.

Haryati, M., (2009), Model \& Teknik Penilaian Pada Tingkat Satuan

Pendidikan, Gaung Persada Press, Jakarta.

Huda, M., (2011), Cooperative Learning: Metode Teknik, Struktur Dan Model Penerapan, Pustaka Pelajar, Yogyakarta.

Husni, S., (2013), Pengaruh Model Pembelajaran Berbasis Proyek Terhadap Peningkatan Hasil Belajar Kognitif Dan Keterampilan Berfikir Kreatif Siswa Sma Pada Topik Listrik Dinamis, Tesis, Pendidikan Ilmu Pengetahuan Alam UPI, Bandung.

Kementrian Pendidikan dan Kebudayaan, (2013), Modul Materi Pelatihan Guru Implementasi Kurikulum 2013, Kemendikbud.

Majid, A., (2008), Perencanaan Pembelajaran, PT Remaja Rosdakarya Offset, Bandung.

Napitupulu, L. E., (2011), Indeks Pendidikan Indonesia

Menurun, http://edukasi.kompas.com/read /2011/03/Indeks-PendidikanIndonesia-Menurun

Rohani, A., (2004), Pengelolaan Pengajaran, PT Rineka Cipta, Jakarta. 
Sani, R. A., (2013), Inovasi Pembelajaran, PT Bumi Aksara, Jakarta.

Slameto, (2003), Belajar dan FaktorFaktor yang Mempengaruhinya, PT Rineka Cipta, Jakarta.

Sudjana, N., (2009), Penilaian Hasil Proses Belajar Mengajar, PT Remaja Rosdakarya, Bandung.

Sudjana, (2005), Metode Statistik, Penerbit Tarsito, Bandung.

Sutirman, (2013), Media \& Modelmodel Pembelajaran Inovatif, PT Graha Ilmu, Yogyakart 